Ph.d.

Center for Subjektivitetsforskning, Københavns Universitet

\title{
ER SKAM EN MORALSK FØLELSE? \\ En sammenligning af individuel og gruppebaseret skam
}

Er skam en moralsk følelse? Efter striden om Muhammed-tegningerne hævdede mange danskere, at ytringsfriheden burde indskrænkes af en bare minimal følelse af anstændighed, og at det at fornærme Islam bare for at fornærme var skamfuldt. Ti år senere gav den danske regerings flygtningefjendtlige politik nogle danskere anledning til at sige, at de skammede sig over at være danskere, eller at en sådan politik var skamfuld for Danmark (Whyte). I disse tilfælde ser skam ud til at blive tildelt en klar, moralsk betydning som vogteren af anstændighed eller dyd. Imidlertid har mange psykologer, især Tangney og Dearing, gjort sig til talsmænd for, at skam er en moralsk set kontraproduktiv følelse, fordi den får os til at reagere på antisociale måder: Den lader os benægte og dække over vores fejl og mangler ved at sky kontakt med andre eller uhæmmet bryde ud i vrede mod dem. Faktisk har Salmela og von Scheve for nylig hævdet, at fremgangen for højrefløjspopulismen i mange lande i Vesten, herunder også Danmark, næres af den psykologiske mekanisme, der omformer skam til vrede (Scheff; Gilligan; J. H. Turner): Når ens identitet, knyttet til arbejde og social status, opleves som sårbar og konstant truet, så forårsager dette en ængstelse over skamfølelsen, som dernæst undertrykkes og forvandles til vrede mod andre. Med denne mekanisme in mente er det plausibelt at 
tænke, at disse "politisk korrekte" udskamnings-strategier (som bruges og anbefales af mange aktivister: miljøforkæmpere, feminister, antiracister og LGBT-bevægelsen (se Jacquet)), har forøget raserireaktionerne via mere undertrykt skam (se Nussbaum kap. 5, 6, 7 om farerne ved udskamning; se også Dolezal). Dette kunne se ud til at være et klart tilfælde af skam, som giver bagslag ved at forårsage aggressiv adfærd.

Denne artikel har til formål at belyse dette dilemma. Jeg vil begynde med en redegørelse for begrebet skam og analysere den relation mellem selv og andre, som etableres i og med skam. Jeg vil forsvare den påstand, at skam er en følelse af social selvbevidsthed, hvor ens eget selvværd fundamentalt medieres af andre. Skam kan trække os i både moralske og umoralske retninger, men i kraft af den relation, den afslører mellem én selv og andre, er den en del af den slags følsomhed, som gør os til moralske væsner. De vigtigste eksempler i denne artikel er imidlertid ikke tilfældene af individuel skam, men af hetero-induceret eller gruppebaseret skam. Dette er emnet for artiklens anden del. I tredje og sidste del stiller jeg spørgsmålet, om skam i samme grad er rationelt passende, dvs. tilpasset situationen, og har den samme betydning, uanset om den er individuel eller gruppebaseret. Jeg vil hævde, at dens vilkår for det rationelt passende er forskellige, mens følelsens struktur og dens generelle etiske betydning forbliver uforandrede.

\section{OM SKAM OG DENS MORALSKE BETYDNING}

Skam bliver typisk beskrevet som en følelse af negativ selvvurdering ("emotion of self-assessment", se Taylor), i den forstand at selve subjektet, der oplever en følelse af skam, vurderer sig selv som fuld af fejl, utilstrækkelig eller mindreværdig. I den henseende bliver skam ofte sammenlignet med skyld, som også er en følelse af negativ selvvurdering. En klassisk måde at udrede forskellen mellem dem er, at jeg i skyld vurderer min adfærd, mens jeg i skam bedømmer mit "hele selv" (cf. Lewis; Taylor; Williams, Shame and Necessity; Deonna et al.). Således ville jeg føle mig skyldig i at have fortalt en specifik løgn til min veninde (jeg fokuserer på, at jeg fortalte hende den løgn i går aftes), men jeg ville skamme mig over at være den slags menneske, som lyver over for sine veninder (som jeg gjorde det over for hende i går aftes). Dog er tingene noget mere komplekse end som så. 
For det første er det "hele selv" et tvetydigt begreb. Deonna, Rodogno og Teroni har bestridt, at alle aspekter af selvet faktisk bliver bedømt i skam (84-85). I deres optik bliver bedømmelsen, undtagen i sjældne tilfælde af ødelæggende skam, indskrænket til det specifikke aspekt, som er relevant for situationen (min bedømmelse af mig selv som ven påvirker ikke min bedømmelse af mig selv som akademiker f.eks.). Det er jeg enig i, men skam bliver stadigvæk oplevet som altomfattende og altoverskyggende og som en ekstrem indsnævring af fokus, hvor de fleste sider af mig selv træder ind i baggrundens mørke, og kun den skamfulde side forbliver synlig i forgrunden: Jeg føler mig reduceret til kun den skamfulde del af mig selv (cf. León; Karlsson og Sjöberg 351; Montes Sánchez, Self-Consciousness, Caring, Relationality).

For det andet kan intentionaliteten i skammen (hvad følelsen drejer sig om, hvad den fokuserer på) ikke reduceres til ét og kun et intentionelt objekt, "selvet". Som Hume bemærkede, bliver selvet altid betragtet som forbundet med et sekundært intentionelt objekt (som han kalder "årsagen" til følelsen), som er tæt forbundet med en selv (286 ff.). ${ }^{1}$ Eftersom denne årsag fortjener en negativ bedømmelse, kan denne bedømmelse overføres til selvet i kraft af deres tætte forbundenhed. Hvis jeg således f.eks. skammer mig over mit snavsede hjem eller min grimme næse, vil jeg opleve, at snavsetheden og grimheden viser negativt tilbage på mig.

For det tredje argumenterer de fleste forskere for (med visse undtagelser, især Deonna et al.), at skam nødvendigvis indebærer en reference til andre: at den er en social følelse. Jeg skammer mig over mig selv i andres åsyn, fordi (jeg føler) de bedømmer mig negativt. Det ser derfor ud til, at jeg i skammen vil føle mig mindreværdig, fordi nogen vurderer mig negativt. I den henseende ville skam adskille sig fra skyld (i en mere eller mindre kantiansk betydning), fordi skyld ikke implicerer denne reference til andre menneskers bedømmelse (se Williams, Shame and Necessity kap. 4.). Skyld ville ganske enkelt indebære kendskab til moralske normer, ens egen pligt og en personlig vurdering af, at man har brudt dem. I denne forstand vil vurderingen i skyldfølelsen altid være klart moralsk, mens den i skam kan være helt og aldeles baseret på ikke-moralsk målestok (skønhed, dygtighed osv.). ${ }^{2}$

1 Se Taylor for en diskussion af hvad Hume præcist mener med "tæt" (28-32).

2 Denne indfaldsvinkel bruges oftest for at opridse kontrasten mellem skam og skyld, 
Så vidt angår andres bedømmelse kan skam også stå i modsætning til ydmygelse. Begge følelser omfatter en følelse af, at man er udsat for ekstern bedømmelse. Men mens man i ydmygelsen gør modstand imod denne bedømmelse, gør man det ikke i skammen. Ydmygelse indebærer en følelse af at blive uretfærdigt undertrykt og nedvurderet, den indebærer, at en anden person retter, angriber eller tilsidesætter én (hvad der ofte, men ikke altid er tilfældet med bevidst udskamning); dette fornemmes som en negativ indflydelse på ens sociale status (Nussbaum 203-04; Deonna et al. 118; Zahavi, Selfand Other 227-28; Montes Sánchez og Zahavi). Hovedforskellen er, at subjektet i ydmygelsen erkender den sociale virkning, den andens bedømmelse har, men samtidig stritter imod denne bedømmelse og ikke inkorporerer den i sin egen vurdering af sig selv (Gilbert). I skam vil man derimod acceptere, at den andens vurdering i en vis forstand er korrekt, eller at den anden har en vis magt til at definere en selv (men cf. Calhoun).

Det er ikke alle, der er enige i, at skam er social i denne betydning af begrebet. Som Williams bemærker, er det ikke alle slags forsamlinger, der kan få os til at skamme os - mennesker, vi foragter, kan typisk ikke (Shame and Necessity 84-85). Han giver et nuanceret forsvar for, at kun forsamlinger, man respekterer, er i stand til dette. Men dette argument er problematisk i de tilfælde af skam, man finder hos overlevere og undertrykte mennesker, hvor det er tvivlsomt, at subjektet kan respektere den udskammende forsamling (se Calhoun; Montes Sánchez og Zahavi). Desuden hævder Deonna, Rodogno og Teroni, at det er muligt at føle skam i ensomhed, og i mange tilfælde af skam kan man ikke identificere en reference til andre end en selv (30-32). Derfor konkluderer de, at skam ikke er social i den forstand, at den ikke behøver at involvere nogen forsamling af mennesker overhovedet: Vi skammer os i vores egne øjne, ikke i andres. Hvis de har ret, er det dog uforklarligt, at forsamlinger har en overvældende kapacitet til at fremkalde og intensivere skam (Smith et al.).

Der findes flere indfaldsvinkler, som kan give os en forståelse af, hvordan skam i ensomhed er mulig, samtidig med at den yder andres altafgø-

især siden Benedict introducerede denne skelnen mellem skamkulturer og skyldkulturer (se Williams, Shame and Necessity for en diskussion af denne modstilling). I den freudianske tradition fremstår skam og skyld langt mere ens (Wollheim). 
rende rolle retfærdighed. Jeg går ind for en sartresk opfattelse: I mine øjne er skam en følelse af social selv-bevidsthed, som sætter selvets udsathed og sociale sårbarhed i forgrunden (Montes Sánchez, Shame and the Internalized Other; cf. Sartre; Guenther; Zahavi, Self and Other). Den fænomenologiske tradition har detaljeret studeret selv-bevidsthed og alle dens dimensioner. Med inspiration fra den kan man skelne imellem mindst to fundamentalt forskellige former for selvopfattelse. Ifølge Zahavi indebærer alle oplevelser en implicit reference til den, der oplever: De er givne for mig (Subjectivity and Selfhood). I den forstand er de minimalt selv-bevidste. Men i følelser som skam, oplever jeg mig selv på en fundamentalt anderledes måde: Ikke som en, der implicit oplever, men som objekt for en andens oplevelse. Jeg oplever, at andre har magt til at opfatte, veje og beskrive mig udefra, og jeg har ikke nogen kontrol over disse beskrivelser. Til trods for denne mangel på kontrol er denne dimension af mig selv også en del af mig, fordi den er, hvad andre kan se, og den former min interaktion med dem (se Sartre 259-60). At være udsat for andre fører til den sociale selv-bevidsthed, som karakteriserer og typisk eksemplificeres af skam: Bevidsthed om mig selv, ikke som et subjekt der opfatter, men som et objekt for den andens opfattelse (Zahavi, Self and Other; Montes Sánchez, Shame and the Internalized Other). Denne udsathed, denne sårbarhed over for andre og denne mangel på kontrol over, hvordan de opfatter mig, giver anledning til skamfølelsen. At føle sig sårbar på denne måde medfører ikke nødvendigvis, at man refererer til en specifik forsamling i hvert eneste tilfælde af skam, men det medfører en relation til en selv set ud fra et intersubjektivt engagement (idet jeg fokuserer på mit udsatte selv).

Med udgangspunkt i en anden tradition har f.eks. Williams og Calhoun udtrykt sig på beslægtede måder ved at påpege, at evnen til at leve med en bestemt identitet, forudsætter at relevante andre anerkender mig som sådan. Skam drejer sig om den sårbarhed, som dette behov for anerkendelse medfører. Williams udtrykker dette ved at sige, at skam altid peger ud mod den verden, jeg ønsker at leve i, og dens forventninger til mig (Shame and Necessity 84). Calhoun hævder, at folks følsomhed over for skam i andres øjne vidner om "deres evne til at tage deres medmennesker i deres sociale verden alvorligt", det betyder, at de anerkender andre som ligestillede deltagere i en fælles moralsk praksis, hvis anskuelser har praktisk vægt til at bestemme, hvem jeg er i hverdagens interaktioner $(138,140)$. 
I mine øjne har betydningen af skam i vores moralske liv at gøre med, at den er en følelse af social selv-bevidsthed, og som sådan forhindrer den os i at henfalde til moralsk solipsisme (cf. Williams, Shame and Necessity; Thomason). Som Thomason udtrykker det:

Det som gør skam værdifuld er, at den har tilbøjelighed til at få os til at se, at vores synspunkter ikke nødvendigvis er de eneste gyldige [...]. En tilbøjelighed til skam forhindrer os i at opfatte den måde, vi ser os selv på, som den højeste autoritet $\mathrm{i}$ vores bedømmelse af os selv[...]. Skam er en følelse, der forhindrer inflation af selvet, ikke fordi det er moralsk godt at bedømme os selv lavere eller ringere, men fordi tilbøjeligheden til skam fordrer, at vi anerkender, at vi ikke altid er de mennesker, vi anser os selv som (21-22).

At være følsom og at lægge vægt på andres meninger om mig betyder på den ene side, at jeg erkender, at jeg er fejlbarlig og modtagelig for at blive korrigeret, og på den anden side, at jeg, til en vis grad, har omsorg for andre (cf. Calhoun). Disse to sider gør mig i stand til at rette ind og lære at forbedre mig (se Aristoteles; Burnyeat; Heller). Empiriske studier viser, at vi beredvilligt anerkende dette, når vi ser skam hos andre. Hvis nogen gør noget skamfuldt i vores nærvær, og vi ser denne person reagerer med skam, så vil vores mening om den krænkende part sandsynligvis være langt mindre negativ, end hvis denne person handler skamløst (de Hooge et al.). Dette skyldes, at skam, ud fra et anden-persons-perspektiv, vidner om, at man bekymrer sig både om andre menneskers mening og om fælles normer og standarder; dette kan så danne modvægt mod personens tidligere svigt og til dels genoprette andre menneskers tillid til den krænkende part (de Hooge et al.). I et studie af fængselsindsatte krænkere finder Tangney og Stuewig desuden frem til, at de eneste mennesker, der ikke er i stand til at føle skam, er psykopater, hvad der befæster forestillingen, om at tilbøjelighed til at føle skam er en del af vores moralske følelsesregister (327).

Alt dette er ikke ensbetydende med, at skam altid er rosværdig. Det er den ikke. Dens forbindelse til umoralske og antisociale handlingstilbøjeligheder er et veletableret faktum. Da den er en så smertefuld følelse, som medfører erkendelse af eget mindreværd eller svigt, motiverer den ofte folk til at lyve og skjule sig, og den kan forvandle sig til vrede og vold, som retter sig mod andre (se Scheff; Gilligan; Tangney og Dearing; J. H. Turner; Maibom; Thomason; Salmela og von Scheve). Desuden medfører 
skam ofte, at man bekymrer sig om andres meninger på en narcissistisk måde: nemlig kun som kilder for en selv til glæde eller smerte og ikke som tanke for andre i deres egen ret (Nussbaum 173-202). Hvis skam skal være rosværdig, skal den være baseret på moralske hensyn og ægte omsorg for andre (Gómez Ramos; Morgan). Men i hvert til fælde udgør tilbøjeligheden til skamfølelse et første trin i den rette retning.

\section{GRUPPEBASERET SKAM}

Indledningens eksempler fra Danmark udgør en meget specifik slags skam, nemlig den som Alessandro Salice og jeg i et tidligere fælles arbejde har navngivet hetero-induceret skam (Montes Sánchez og Salice; Salice og Montes Sánchez), eller som socialpsykologer snarere kalder gruppebaseret skam (se Lickel et al.). ${ }^{3}$ I disse eksempler er skam ikke forbundet med en individuel handling eller et individuelt karaktertræk, men den er relateret til noget, som en anden gør. Handlinger, udført af nogle danske satiretegnere og en avis, eller udført af en minister, bliver åbenbart anset for at volde enhver dansker skam, uanset om han eller hun overhovedet har bidraget til sådanne handlinger. Disse tilfælde er ikke mærkelige eller usædvanlige; vi oplever ofte, at vi selv føler skam over vores families, venners eller landsmænds handlinger eller karaktertræk (se også Scheler). Betyder dette, at skam alligevel ikke er selv-bevidst? Nej, slet ikke. I min optik viser disse tilfælde blot, at vores selv ikke er solipsistisk eller kun er indesluttet i sig selv.

Det, som er på spil i de ovennævnte eksempler, er det, som socialpsykologer kalder vores sociale selv, det vil sige de sider af identiteten, som hidrører fra, at man identificerer sig selv som medlem af en gruppe (Brewer; Brewer og Gardner). Jeg kan anerkende, at jeg med andre deler et vist karakteristikon, som gør, at vi kan klassificere os sammen, f.eks. vores blodtype. Jeg kan også anerkende, at jeg tilhører en bestemt gruppe, hvad angår lov og ret og institutioner, f.eks. at jeg er borger i et bestemt land eller ansat i et bestemt firma. Men jeg kan gøre alt dette uden at grup-

3 Alessandro Salice og jeg havde en række grunde til at skelne mellem "hetero-inducerede" og gruppebaserede selvbevidste følelser, men disse er ikke afgørende for denne artikel. Se i stedet Montes Sánchez og Salice; Salice og Montes Sánchez. 
peidentificere mig med disse grupper, uden at mine følelser, tanker eller handlinger på nogen måde bliver påvirket af, at jeg anerkender disse fakta. Gruppeidentifikation ændrer alt dette, sådan at man begynder med at leve gennem gruppen "indefra" ved at anskue situationerne fra et vi-perspektiv: Et væld af psykologisk litteratur udpeger flg. væsentligste biprodukter af gruppeidentifikation og vi-perspektiv: en tydelig prædisposition for altruisme i forhold til gruppemedlemmerne for at dele følelser, for sympati, for kollektive handlinger, for vi-tale osv. (J. C. Turner 50). Gruppeidentifikation består altså af denne psykologiske proces, hvor jeg kommer frem til at anskue mine oplevelser i vi-termer. Når først gruppeidentifikationen er indtruffet, gennemgår subjektets selv-bevidsthed en specifik forvandling: Selvet bliver nu indoptaget i et vi, et vi, som andre også er indoptaget i, og som selvet føler sig knyttet til.

For at denne psykologiske proces skal indtræffe, er et faktisk gruppemedlemsskab ikke tilstrækkeligt. ${ }^{4}$ Det altafgørende er det iøjnefaldende element ("salience"); man skal være i en situation, hvor ens fællestræk med andre bliver iøjnefaldende for en og indvirker på din følelse af dit selv. ${ }^{5}$ I nogle situationer kan man derfor gruppeidentificere sig med nogen, som gør noget skamfuldt, og derved selv komme til at føle skam, skamfuld på ens sociale selvs vegne i den udstrækning, man er medlem af os. Tænk på tilfældet med en dansker, der ser nyhederne om den danske regerings flygtningefjendtlige politik og skammer sig over det: Den internationale opsigt, historien vækker, eller tanken om de skuffede forhåbninger hos asylsøgerne, som, under kummerlige omstændigheder, er flygtet fra krig. Her er det centrale, at denne tv-seer deler visse egenskaber med andre mennesker - hun er eksempelvis dansk ligesom den "krænkende" regerings embedsmænd, og hun er privilegeret ved at være født i et rigt og fredeligt land (se Oxfeldt, "Skandinavisk skyld"; Oxfeldt, Skandinaviske fortellinger om skyld og privilegier i en globaliseringstid)). Dette udløser gruppeidentifika-

4 Faktisk er det heller ikke nødvendigt (Montes Sánchez og Salice). Klassiske socialpsykologiske forsøg (Tajfel; Tajfel et al.) viser at uendelig små fællestræk kan grundlægge "minimalgrupper".

5 Det må medgives, at begrebet "salience" er temmelig vanskelig at karakterisere (se Oakes). 
tionen, sådan at denne tv-seer begynder at anskue situationen i vi-termer. Da seeren opfatter den danske regerings embedsmænd som medlemmer af den samme gruppe, som hun selv tilhører, føler hun sig skamfuld. Selv om årsagen eller situationen, der førte tv-seeren til at føle skam, ikke skyldes hende selv, så angår skamfølelsen ikke desto mindre hende selv, men den drejer sig om hende selv qua medlem af gruppen bestående af alle danskere.

Faktisk kunne man argumentere for, at den historiske udvikling af flygtningepolitik i Danmark, og måden hvorpå den nationalt så vel som internationalt er blevet offentliggjort, giver grobund for gruppebaseret skam. Som Thomas Gammeltoft-Hansen har argumenteret, har Danmark over de sidste tyve år udviklet sig fra at være et af de mest åbne og imødekommende lande for flygtninge i Europa, til at blive et førende europæisk land, når det kommer til indirekte afskrækkelsespolitikker. I modsætning til direkte grænsekontrol og lignende politikker, fungerer indirekte afskrækkelsespolitikker ved at forsøge at gøre et land så ugæstfrit for asylansøgere som muligt ved at indføre bureaukratiske og juridiske barrierer rettet mod deres mulighed for at opnå opholdstilladelse og familiesammenføring og ved at skære i deres velfærdsydelser. Men sådanne politikker virker kun, forudsat asylansøgerne kender til dem, eller snarere har kendskab til pågældende lands rygte som ugæstfrit. Derfor beror sådanne politikker i høj grad på, hvad Gammeltoft-Hansen kalder negative nation branding: Altså at fremstille sig selv som en lidet ønskværdig destination overfor potentielle asylansøgere. For eksempel førte den danske regering i 2015 en kampagne i arabisksprogede aviser, hvori den gjorde opmærksom på nylige asyl- og immigrationsstramninger. Men sådanne tiltag risikerer at smitte af på landets overordnede omdømme. De gør danskerne opmærksomme på eksistensen af en international offentlighed, der sandsynligvis opfatter dem som ugæstfrie og selviske, og dette får mange danskere til at skamme sig på deres lands vegne (især dem der i 80'erne kæmpede for liberale immigrations- og asylpolitikker: Se Gammeltoft-Hansen 101). Et andet eksempel stammer fra den internationale presses nedslag på historien om en af de nye asyl- og immigrationsstramninger, der ikke de facto var den mest graverende, men som tog sig usædvanlig slet ud: politiets mulighed for at konfiskere flygtninges ejendele. Adskillige europæiske aviser drog sammenligninger med Det Tredje Rige og bragte karikaturer af den danske 
statsminister som Hitler. Sådanne associationer var skam-påførende for mange danskere, og regeringen reagerede med foragt, hvilket, som tidligere anført, kan ses som et tegn på omformet skam, eller som resultat af en følelse af ydmygelse.

\section{OM DEN MORALSKE BETYDNING AF GRUPPEBASERET SKAM}

De eksempler, jeg anførte i denne artikels indledning, er derfor eksempler på gruppebaseret skam. Og derfor er spørgsmålet nu: Er gruppebaseret skam det samme som individuel skam i henseende til moralsk betydning? Bekymringen er her, at der nok principielt kunne være noget forkert $\mathrm{i}$ at bedømme os selv ud fra andres handle- eller væremåde, at en sådan bedømmelse altid drejer sig om det forkerte mål, for jeg burde bedømme den anden, ikke mig selv (se Salmela og Sullivan). Jeg burde snarere end skam føle foragt for eller indignation over den anden, for det er, hvad situationen inviterer.

For at få en klarere forståelse af ovenstående vil jeg her benytte mig af den skelnen, som D'Arms og Jacobson har etableret i deres berømte artikel, "The Moralistic Fallacy". Heri skelner de mellem to måder, som "passende" [appropriate] kan forstås på: 1) en følelse kan være rationelt passende i deskriptiv forstand ("fitting"), dvs. den repræsenterer korrekt det emne, den drejer sig om, eller 2) den kan være moralsk passende eller upassende ("morally appropriate or inappropriate"), dvs. den kan blive bedømt som dydig eller forkastelig. Det altafgørende er her, at det rationelt passende og det moralsk passende ofte går i hver sin retning. Min misundelse kan godt korrekt repræsentere min rival som en, der har noget, som jeg også gerne vil have og ikke kan få - for nu at bruge D'Arms og Jacobsons eksempel: Hun fik den forfremmelse, jeg også ønskede at få. I den forstand er min misundelse rationelt passende. Til trods for det, kan det stadig være moralsk upassende, dvs. forkasteligt, at føle misundelse i dette tilfælde. Ifølge D’Arms og Jacobson, har den manglende anerkendelse af denne forskel affødt en del forvirring i debatterne om den moralske betydning af følelser. Ifølge denne distinktion er den bekymring, jeg udtrykte om gruppebaseret skam, at den nok aldrig kan repræsentere fakta korrekt, siden den er en bedømmelse af en selv foretaget ud fra en andens fejl. Hvis gruppebaseret skam principielt aldrig var dækkende på denne måde, ville det være vanskeligt at se, hvordan 
det nogensinde kan være moralsk godt at føle den, eller hvordan den kan have en konstruktiv rolle i vores etiske liv.

I litteraturen om massegrusomheder og de moralske reaktioner, de burde afføde hos vidner eller tilskuere, som hører om dem på geografisk eller tidsmæssig lang afstand, er det muligt at spore forsøg på at påpege, at skam kan være en passende moralsk respons eller endda netop den følelse, vi burde nære, selv om den kan ses som rationelt upassende i streng forstand (se f.eks. Morgan; Bauman; Geras. De bruger dog ikke denne terminologi eller denne skelnen, men jeg mener, at nogle af deres argumenter kan tolkes på denne måde). Disse tilfælde af skam kan nogle gange fortolkes som skam over ens egen fejhed, fordi man af frygt vendte det blinde øje til de rædsler, der blev begået mod andre i lighed med Baumans eksempel på, at man nægter at give husly til sin forfulgte nabo (205). I sådanne tilfælde kunne skam i princippet være rationelt passende, men den ville også være individuel og ikke gruppebaseret. Den ville nemlig betyde, at man skammer sig over sin egen mangelfuldhed.

Når derimod Morgan beskriver sin egen skam over folkemordet i Rwanda i sammenhæng med de vestlige regeringers passivitet over for begivenhederne (26), så kan hans skam kun tolkes som gruppebaseret i lighed med det tidligere eksempel med skamfuldheden over den danske regerings flygtningefjendtlige politik. ${ }^{6} \mathrm{De}$, som forsvarer skam som moralsk retfærdiggjort i sådanne tilfælde, ser ud til at forlange, at der skal gribes konkret ind i den slags uhyrligheder; dvs., at ens moralske respons fra en tilskuerposition ikke er nok; man skal gribes så dybt, at man ser sig selv som part i sagen, fordi sådanne uhyrligheder i en vis forstand angår os alle; og her er skam netop den respons. I modsætning til skyld behøver skam ikke forbindes med moralsk ansvar (man kan sagtens føle skam over ting som man ikke har nogen del i, men som bare overgår en); den kan imidlertid få en til at stå ansigt til ansigt med sider af en selv, som evt. kan gøre en til medskyldig eller næsten medskyldig. I sin behandling af en anden slags følelse end skam har Bernard Williams gjort sig til talsmand for begrebet agent-anger ("agent-regret"), som

6 Morgans skam kan ikke være individuel, da han ikke er direkte impliceret i situationen i Rwanda: Han er en amerikansk borger, der skammer sig over den amerikanske regerings passive politik og laden stå til ift. Rwanda. 
gør det muligt at redegøre for tilfælde af, hvad han anser for moralsk passende, men strictu sensu, ikke rationelt passende skyldfølelser (Williams, Moral Luck kap.1; Williams, Shame and Necessity 92-94).

Diskussionen er her yderst kompleks, og jeg har ikke plads til at gå mere detaljeret ind i den (men se Montes Sánchez og Zahavi). Eftersom det rationelt passende ikke er det samme som moralsk godhed, vil jeg nøjes med at påpege, at der kunne tænkes tilfælde, hvor man kunne finde en moralsk retfærdiggørelse for at nære en følelse, der ikke er rationelt passende i begrebets strengeste forstand. Men jeg vil hævde, at gruppebaseret skam, præcis som individuel skam, i princippet kan være rationelt passende. Selvet er ikke solipsistisk eller isoleret. En afgørende faktor i det, der konstituerer vores selv, er vores sociale relationer, dels fordi de andre peger på og former vores egne værdier, og dels fordi vores væren i verden i høj grad afhænger af, hvordan andre opfatter og behandler os (Haslanger). Derfor kan der være situationer, hvor "hvem jeg er" afhænger af mine sociale kontakter og kan bedømmes ud fra dem.

Jeg har hævdet, at gruppebaseret skam er skam rettet mod mit sociale selv, dvs. mod mig selv som medlem af den gruppe, der også tæller den, som påfører skam. Konteksten gør vores fællestræk iøjnefaldende på en måde, som får mig til at gruppeidentificere mig med den, der påfører skam. Hvad er betingelserne for at en sådan følelse kan være rationelt passende? Dette er et ganske kompliceret spørgsmål (se Salmela og Sulivan), men lad mig kort fremhæve to overvejelser. For det første hævdede jeg jo tidligere, at gruppeidentifikation kan indtræffe, selv om man ikke er faktisk medlem af en gruppe. Altså er den første betingelse for at gruppebaseret skam kan siges at være rationelt passende, at det skamfulde subjekt faktisk tilhører den samme gruppe som den skam-påførende anden (se Salice og Montes Sánchez n. 8). For eksempel er der en rationel basis for at min danske kollega skammer sig over den danske flygtningefjendtlige politik, mens det er meget mere tvivlsomt, om en nyligt ankommen, japansk gæsteforsker på rationelt passende vis kan skamme sig over den, da hun ikke har identitetsforbindelser til Danmark. ${ }^{7}$

7 Dette betyder ikke at alle danskere er forpligtet til at føle således, men kun, at for de der gør, kan følelsen være rationelt passende. 
For det andet skal situationen anskues fra den rigtige vinkel, selv når et gruppemedlemsskab er fast grundlagt. Det ser ud til at være muligt at anskue situationen ud fra en overdrevent individualistisk vinkel, så at det skamfulde subjekt begynder at påtage sig en del af den skyld, som rettelig kun er den andens. Dette ville gøre skam rationelt upassende. Det kunne være tilfældet, hvis f.eks. et overdrevent skamfuldt barn begynder at skyde skylden på sig selv over, at dets forældre er alkoholikere (se Salmela og Sullivan). Dette er ikke rationelt passende, for det svarer til at overføre et individs fejl til et andet individ, nemlig en selv i kraft af, at de tilhører den samme gruppe, men fejlen bliver stadig anskuet under en rent individualistisk vinkel: Deres individuelle fejl afslører min individuelle fejl, hvad der helt klart er rationelt upassende. Men gruppebaseret skam leder ikke nødvendigvis til en rationelt upassende tilskrivelse af skyld. Tag blot dette eksempel fra litteraturens verden: Når Elizabeth i Stolthed og fordom skammer sig over sin yngre søster, skyldes det, som hun senere fortæller sin far, "vores (families) betydning, vores anseelse i verden må blive påvirket af den ustyrlige letbevægelighed [...] og foragt for enhver selvbeherskelse, som præger Lydias karakter" (Austen kap. 41). Elizabeth placerer skylden dér, hvor den hører til, nemlig til hendes søster Lydia, men vurderer korrekt, i den givne sociale kontekst, at Lydias opførsel påvirker hele familiens anseelse, inklusiv hendes egen. Dette er for mig at se et eksempel på rationelt passende gruppebaseret skam. På samme vis mener jeg, at det at skamme sig over ens regerings politik kan anskues som rationelt passende.

Siden gruppebaseret skam, lige som individuel skam og enhver anden følelse, også kan være enten rationelt passende eller upassende, burde dette mere generelt ikke have nogen indvirkning på dens moralske betydning. I enighed med Williams og Thomason har jeg hævdet, at den moralske betydning af skam ligger i dens potentiale til at skærme os mod moralsk solipsisme. I denne henseende mener jeg ikke, at gruppebaseret skam afviger meget fra individuel skam. Som den individuelle skam (og andre følelser af selv-bedømmelse) kan den være narcissistisk (Žižek; Nussbaum kap. 4), men igen ligesom individuel skam kan den også ende med at motivere os til en (kollektiv) lærings- og ændringsproces (Burnyeat; Jacquet).

Naturligvis komplicerer gruppedimensionen yderligere spørgsmålet om, hvad moralsk solipsisme eller narcissisme overhovedet er, for kan 
man tale om, at en gruppe kan være moralsk solipsistisk i samme forstand, som et individ kan være moralsk solipsistisk? Kan gruppen i lighed med individet undslippe den moralske solipsisme? Jeg mener at en gruppe, ligesom et individ, kan være "moralsk solipsistisk" i den forstand at den kan være fuldstændig døv overfor andre - dem, som ikke er medlemmer af gruppen. En gruppe kan være fuldstændig indelukket, intolerant overfor det anderledes og anti-pluralistisk. For et individ kan det at lære at lytte til andre kræve en del arbejde med en selv; tænk blot på, hvordan vi op gennem barn- og ungdom må lære, at vi ikke er universets centrum. For en gruppe vil denne proces se ganske anderledes ud. En reaktion på gruppebaseret skam kunne således være et socialt eller politisk engagement $i$ at ændre gruppens værdier og holdninger, eller hvis det er umuligt, kunne den føre individet til at gøre sig fri af gruppen. Hvordan udmønter dette sig konkret? I eksemplet med de danske flygtningefjendtlige politik var der selv sagt en masse offentlig debat i medierne, i hvilken nogle kommentatorer gjorde opmærksom på deres egen skyldfølelse og anklagede regeringen for at være umoralsk og skamløs (Whyte). Nogle danskere tog til den tyske grænse for at hjælpe flygtninge til Sverige (se f.eks. Bundgård Fals; Hartung; "Danskere sejlede flygtning til Sverige"), og græsrodsbevægelsen Venligboerne, en gruppe dedikeret til at hjælpe migranter, voksede voldsomt. ${ }^{8}$

Som de eksempler, jeg har arbejdet med, viser, må disse spørgsmål afgjort henregnes til det socio-politiske domæne. En omhyggelig udforskning af disse emner må udfoldes i en anden artikel, men lad mig knytte en kort kommentar til Jill Lockes bog, Democracy and the Death of Shame, i hvilken hun fremfører en kritik af forsøg på at forsvare skam som en positiv politisk kraft. Hun argumenterer for, at beklagelser over, at folk handler skamløst i det offentlige rum, og opfordringer til en tilbagevenden til skam og anstændighed typisk er skalkeskjul for at gøre undertrykte grupper tavse, når de kræver politisk taletid til deres historier om lidelse og til deres krav om forandring. Dette blokerer de eneste muligheder sådanne undertrykte grupper har for politisk handling (hun nævner for eksempel Black Lives Matter, feminister og LGBT aktivister). Hun synes at mene, at skam altid bliver brugt som forsvar for gamle, etablerede normer, samt 
at ægte demokrati kræver, at "unashamed citizens" (ikke skyldtyngede borgere) bryder med disse normer. Hun er mistænksom overfor en hvilken som helst diskurs, der tilskriver værdi til skam i det offentlige rum, fordi denne forsøger at indramme, hvad der bør siges, og hvad der ikke bør siges offentligt. Udfordrer dette min tese om skammens moralske værdi?

Lad mig begynde med at tilslutte mig idéen om, at skam er en ambivalent og farlig kraft, hvorend den bruges, og at meget politisk diskurs om skam dækkes af hendes beskrivelse. Men hendes advarsler kan ikke anvendes direkte på mine pointer, da jeg argumenterer fra et fænomenologisk og moralsk psykologisk perspektiv. Jeg argumenter for, at oplevelsen af individuel og gruppebaseret skam kan være en positiv kraft i folks moralske liv, samt at den alt andet lige er en grundlæggende del af vores socialitet og relation til andre. Set i lyset af hendes kommentarer omkring Williams og umuligheden og uønskværdigheden af at fjerne skam fra folks liv, tror jeg, at Locke ville være enig med mig (174-175).

Der er to andre spørgsmål, der er centrale for Locke, og som jeg ikke kommer ind på. For det første: Hvilket politisk udfald har det, når man appellerer til eksisterende sociale normer, der fastsætter, hvad der er skammeligt eller ordentligt i samfundet? For det andet: Kan udskamning nogensinde bruges produktivt i politik? Jeg er enig med Locke i, at de eksisterende sociale normer for skam ofte bruges mere eller mindre reaktionært i politisk diskurs (Locke 172), hvad Carroll dog kritiserer. Jeg er også enig med Locke $i$, at man skal være tilbageholdende med udskammende handlinger, da de kan være ganske farlige (se Salmela og von Scheve). Men jeg synes, at Locke underspiller vigtigheden af udskamningsstrategier, som de anvendes af hendes "unashamed citizens": Aktivister, der afbryder politisk diskurs med deres krav. Sådanne handlinger indebærer netop udskamning: "at udstille en overtræder til offentlig misbilligelse" (Jacquet, kap. 1). Jeg ved ikke, hvordan politisk aktivisme skulle kunne frigøre sig fra denne normative side. Jeg vil hævde, at det mange aktivister gør, netop er at udfordre rammerne for hvad samfundet fastsætter som skamfuldt, og at kæmpe for at rammerne for anstændighed placeres andetsteds. Det er delvist indbegrebet af en bevægelse som Venligboerne, at det er uacceptabelt, det vil sige umoralsk og skamfuldt, at vende det blinde øje til folk i nød i den nationale sikkerheds navn. Nogle få medlemmer af en større gruppe (Venligboerne) ser en 
modsætning mellem, hvad de føler er skamfuldt for gruppen (danskerne), og hvad andre medlemmer føler er skamfuldt for den samme gruppe, og de indleder en offentlig diskussion (eller en offentlig kamp) for at ændre de moralske rammer for alle. Således mener jeg, at Locke er for hurtig til at affeje Jacquets forslag om brugen af udskamning som et værktøj for social forandring, og at et komplet argument imod dette kræver mere, end hvad Locke tilbyder (se også Carroll).

Som jeg ser det, er der hos Locke det generelle problem, hun ikke klart skelner mellem forskellige skamrelaterede fænomener. Termen "skam" betegner hos Locke: 1) skam som en subjektiv følelse, 2) regler og "paradigmescenarier" (de Sousa) for skam i forskellige samfund, 3) udskamning og ydmygelse, og 4) stigmatisering og vanære. Jeg forsøger herimod at analysere den følelsesmæssige oplevelse af skam og dens fænomenologiske struktur, samt at klarlægge dens rolle i vores moralske psykologi. Det er min overbevisning at både individuel og gruppebaseret skam har en vigtig rolle at spille heri.

\section{KONKLUSION}

I denne artikel har jeg hævdet, at skam er en følelse af social selv-bevidsthed, og som sådan kan den skærme os kraftigt mod moralsk solipsisme. Skammen presser os til at tage andres mening i betragtning, når vi bedømmer os selv. Det gør skammen til en ambivalent kraft: Den kan være undertrykkende og lægge låg på vores individualitet, men den kan også forhindre os i at tilsidesætte andre på en selvisk måde og åbne vores øjne for mangler, vi ikke kunne se. Det betyder ikke at skammen altid er rosværdig: Et ønske om at blive vores skam kvit eller undertrykke den kan føre til umoralske handlinger såsom at lyve eller angribe andre (Gilligan; Tangney og Dearing). Der er fremført argumenter om, at højrefløjspopulisme og xenofobi er forankret i ængstelse over skamfølelsen: Når ens identitet, som er forbundet med arbejde og status, bliver truet, bliver skammen omformet ved at beskylde fremmede og angribe dem (se Salmela og Von Scheve).

Derfor kan skam blive et farligt værktøj i politik. Ikke desto mindre, set i et moralpsykologisk perspektiv, er det tilbøjeligheden til at føle skam, der sætter os i stand til at lære af vores fejltagelser og ændre os til det bedre. 
Hetero-induceret gruppe-baseret skam adskiller sig i denne henseende ikke fra individuel skam. Jeg vil endda hævde, at gruppebaseret skam kan motivere filantropiske handlinger af typen set i reaktionen på Danmarks flygtningefjendtlige politik. Borgere, som til dels skammer sig over deres danskhed på baggrund af, hvad de ser som deres regerings fremmedfjendske politik, griber ind gennem bevægelser som Venligboerne for at ændre deres gruppes, det vil sige danskernes, holdning. Eftersom gruppebaseret skam afhænger af gruppeidentifikation, adskiller dens vilkår for det rationelt passende sig fra dem, der gælder for individuel skam: Blandt disse vilkår forudsætter rationelt passende, gruppebaseret skam, at det subjekt, der skammer sig, rent faktisk er medlem af den relevante gruppe, og at subjektet tilgår situationen på gruppepræmisser, det vil sige tildeler ansvar kollektivt og ikke individuelt.

På trods af disse forskelle mellem individuel og gruppebaseret skam, er de begge i stand til at skærme os mod moralsk solipsisme. Men dette er ikke tilstrækkeligt til at anbefale det som politisk værktøj. Offentlig udskamning og dets diskurser har konsekvenser, jeg ikke har forsøgt at analysere her, og de kræver en grundig behandling. Men at være forsigtig omkring udskamningens offentlige brug bør ikke lede os til at tilsidesætte skammens vigtige rolle i vores individuelle og kollektive moralske psykologi. ${ }^{9}$

Oversat fra engelsk af Ditte Høffding og Simon Høffding

ALBA MONTES SÁNCHEz forsker i følelsernes filosofi og moralpsykologi i krydsfeltet mellem bevidsthedsfilosofi og fænomenologi, senest som Post.doc på Center for Subjektivitetsforskning ved Københavns Universitet. Hendes ph.d.-afhandling handlede om skammens moralske betydning. I det multidisciplinære projekt "The Genomic History of Denmark" har hun behandlet spørgsmål om personlig identitet og gruppemedlemskab samt de etiske spørgsmål, der opstår i forbindelse med populationsgenetik og opdagelsen af vores "deep past." Hendes forskning er udgivet i tidsskrifter så som Frontiers in

9 Jeg vil gerne takke Ditte Høffding og Simon Høffding for deres uvurderlige hjælp med at oversætte min oprindelige, engelske kladde til dansk og med at behandle senere revisioner. Denne proces ledte til at klargøre mindre tydelige passager. Jeg vil også takke Alessandro Salice for indsigtsfulde kommentarer til den første engelske version. Slutteligt takker jeg redaktørerne af dette særnummer, Devika Sharma og Elisabeth Oxfeldt, samt en anonym bedømmer. Deres nyttige kommentarer hjalp mig til mange forbedringer af den danske version. 
Psychology, Journal of Consciousness Studies, Etica e Politica/Ethics and Politics, og Azafea.

\section{IS SHAME A MORAL EMOTION?}

Comparing Individual and Group-based Shame

Is shame a moral emotion? After the Muhammad cartoons controversy, many Danes argued that freedom of speech should be limited by a sense of decency, that insulting Islam for the sake of insult was shameful. Ten years later, the Danish government's anti-refugee policy led some to say they were ashamed of being Danish. Here shame is given moral significance as the guardian of decency. However, psychologists like Tangney and Dearing have claimed that shame is morally counter-productive: it makes us react in antisocial ways, covering up our failings, shunning contact with others or lashing out in anger. Some have recently argued that the rise of rightwing populism in many Western nations is fueled by the psychological mechanism of transforming shame into rage. This seems a case of shame backfiring to cause antisocial behavior.

In this paper, I seek to illuminate this dilemma by analyzing how self and others relate in shame. I defend that shame is an emotion of social self-consciousness, where one's own self-assessment is fundamentally mediated by others. It may pull us in moral and immoral directions, but it is anyway part of the sensibilities that make us moral. My central examples, though, are cases of group-based shame. Is shame equally appropriate, and does it have the same significance, when it is group-based? I argue that the conditions of appropriateness change, but the structure of the emotion and its moral significance remains unchanged.

\section{KEYWORDS}

DK: skam, gruppebaseret skam, hetero-induceret skam, moralske følelser, selvbedømmende følelser, følelsernes situationstilpasning.

EN: shame, group-based shame, hetero-induced shame, moral emotions, emotions of self-assessment, appropriateness of emotions 


\section{LITTERATUR}

Aristoteles. On Rhetoric: A Theory of Civic Discourse. Redigeret af George Alexander Kennedy. Oxford: Oxford University Press, 1991.

Austen, Jane. Pride and Prejudice. Red. Pat Rogers. Cambridge: Cambridge University Press, 2006.

Bauman, Zygmunt. Modernity and the Holocaust. Cambridge: Polity Press, 1989.

Benedict, Ruth. The Chrysanthemum and the Sword:Patterns of Japanese Culture. New York: Houghton Mifflin Harcourt, 2005.

Brewer, Marilynn B. "The Social Self: On Being the Same and Different at the Same Time". Personality and Social Psychology Bulletin 17, nr. 5 (1991): 475-82. psp.sagepub.com, doi:10.1177/0146167291175001.

Brewer, Marilynn B. og Wendi Gardner. "Who is this 'We'? Levels of collective identity and selfrepresentations". Journal of Personality and Social Psychology 71, nr. 1 (1996): 83-93. APA PsycNET, doi:10.1037/0022-3514.71.1.83.

Bundgård Fals, Katinka. "Mad, vand og 'Welcome to Denmark' - men flygtningene udeblev". Politiken, 7. september 2015, https://politiken.dk/udland/fokus_int/ Flygtningestroem/art5588240/Mad-vand-og-Welcome-to-Denmark-men-flygtningene-udeblev.

Burnyeat, Myles. "Aristotle on Learning to Be Good". Essays on Aristotle's Ethics. Red. Amélie Rorty. Berkeley: University of California Press, 1980. 69-92.

Calhoun, Cheshire. "An Apology for Moral Shame". Journal of Political Philosophy 12, nr. 2 (2004): 127-146. Wiley Online Library, doi:10.1111/j.1467-9760.2004.00194.x.

Carroll, Ross. "Review of: Democracy and the death of shame: Political equality and social disturbance by Jill Locke". Contemporary Political Theory (2017): 1-4. <https://doi. org/10.1057/s41296-017-0133-z>.

"Danskere sejlede flygtning til Sverige: Vi var nødt til at bryde loven". DR 8. september 2015. Set 16. januar 2018 https://www.dr.dk/nyheder/indland/danskere-sejlede-flygtning-til-sverige-vi-var-noedt-til-bryde-loven.

D’Arms, Justin og Daniel Jacobson. "The Moralistic Fallacy: On the 'Appropriateness' of Emotions". Philosophy and Phenomenological Research 61, nr. 1 (2000): 65-90. JSTOR, doi:10.2307/2653403.

de Hooge, Ilona E., et al.. "Restore and protect motivations following shame". Cognition \& Emotion 24, nr. 1 (2010): 111-27. Taylor and Francis+NEJM, doi:10.1080/02699930802584466.

Deonna, Julien, Raffaele Rodogno og Fabrice Teroni. In Defense of Shame: The Faces of an Emotion. New York: Oxford University Press, 2011.

de Sousa, Ronald. The Rationality of Emotion. Cambridge MA: MIT Press, 1990.

Dolezal, Luna. "Review of Jill Locke, 'Democracy and the Death of Shame: Political Equality and Social Disturbance'". Hypatia, bd. Gender and the Politics of Shame Special Issue (2017). http://hypatiareviews.org/reviews/content/332.

Gameltoft-Hansen, Thomas. "Refugee policy as 'negative nation branding': the case of Denmark and the Nordics". Danish Foreign Policy Yearbook 2017. Red. Kristian Fischer og Hans Mouritzen. København: DIIS - Danish Institute for International 
Studies, 2017. 99-125.

Geras, Norman. The Contract of Mutual Indifference: Political Philosophy After the Holocaust. London: Verso, 1998.

Gilbert, Paul. "What Is Shame? Some Core Issues and Controversies". Shame: Interpersonal Behavior, Psychopathology, and Culture. Red. Paul Gilbert og Bernice Andrews. New York: Oxford University Press, 1998. 3-38.

Gilligan, James. "Shame, Guilt, and Violence". Social Research: An International Quarterly 70, nr. 4 (2003): 1149-80.

Gómez Ramos, Antonio. "Cuerpo, dolor y verdad. A propósito de un relato de J. M. Coetzee". Nadie sabe lo que puede un cuerpo: variaciones sobre el cuerpo y sus destinos. Red. Natividad Corral. Madrid: Talasa Ediciones, 2005. 13-28.

Guenther, Lisa. "Shame and the temporality of social life". Continental Philosophy Review 44, nr. 1 (2011): 23-39. SpringerLink, doi:10.1007/s11007-011-9164-y.

Hartung, Berit. "Vil du hjælpe? Det må du gøre, hvis du møder en flygtning". www.b.dk, 8. september 2015, https://www.b.dk/content/item/117041.

Haslanger, Sally. Resisting Reality: Social Construction and Social Critique. Oxford: Oxford University Press, 2012.

Heller, Agnes. "Five Approaches to the Phenomenon of Shame". Social Research: An International Quarterly 70, nr. 4 (2003): 1015-30.

Hume, David. A Treatise of Human Nature. Red. L. A. Selby-Bigge og P. H. Nidditch (2. udg.). Oxford: Claredon Press, 1978.

Jacquet, Jennifer. Is Shame Necessary?: New Uses for an Old Tool. New York: Knopf Doubleday Publishing Group, 2015.

Karlsson, Gunnar og Lennart Gustav Sjöberg. "The Experiences of Guilt and Shame: A Phenomenological-Psychological Study". Human Studies 32, nr. 3 (2009): 335-55. link.springer.com, doi:10.1007/s10746-009-9123-3.

León, Felipe. "Shame and Selfhood". Phänomenologische Forschungen 2012 (2013): 1-19.

Lewis, Helen B. Shame and Guilt in Neurosis. New York: International Universities Press Inc., 1971.

Lickel, Brian, Rachel R. Steele og Toni Schmader. "Group-Based Shame and Guilt: Emerging Directions in Research". Social and Personality Psychology Compass 5, nr. 3 (2011): 153-63. doi:10.1111/j.1751-9004.2010.00340.x.

Locke, Jill. Democracy and the Death of Shame: Political Equality and Social Disturbance. Cambridge: Cambridge University Press, 2016.

Maibom, Heidi L. "The Descent of Shame". Philosophy and Phenomenological Research 80, nr. 3 (2010): 566-94. Wiley Online Library, doi:10.1111/j.1933-1592.2010.00341.x.

Montes Sánchez, Alba. Self-Consciousness, Caring, Relationality: An Investigation into the Experience of Shame and Its Ethical Role. PhD-afhandling, Universidad Carlos III de Madrid, 2014. e-archivo.uc3m.es, http://e-archivo.uc3m.es/handle/10016/19454.

Montes Sánchez, Alba. "Shame and the Internalized Other". Etica \& Politica / Ethics \& Politics XVII, nr. 2 (2015): 180-99.

Montes Sánchez, Alba og Alessandro Salice. "Feeling Ashamed of Myself Because of You". Embodiment, Enaction, and Culture-Investigating the Constitution of the Shared 
World. Red. Christoph Durt, Thomas Fuchs og Christian Tewes. Cambridge MA: MIT Press, 2017. 229-44.

Montes Sánchez, Alba og Dan Zahavi. "Unravelling the meaning of survivor shame". Emotions and Mass Atrocities: Philosophical and Theoretical Perspectives. Red. Thomas Brudholm og Johannes Lang. Cambridge: Cambridge University Press, 2018. Morgan, Michael L. On Shame. New York: Routledge, 2008.

Nussbaum, Martha C. Hiding from Humanity: Disgust, Shame, and the Law. New Ed. Princeton and Oxford: Princeton University Press, 2006.

Oakes, P. J. "The Salience of Social Categories". Rediscovering the Social Group, a Self-Categorization Theory. Red. John C. Turner. Oxford: Basil Blackwell, 1987. 117-41.

Oxfeldt, Elisabeth. "Skandinavisk skyld: Fornuft og følelse i Margreth Olins De andre". Samtiden 124, nr. 3-4 (2016): 67-74.

Oxfeldt, Elisabeth, redaktør. Skandinaviske fortellinger om skyld og privilegier $i$ en globaliseringstid (1. udg.). Oslo: Universitetsforlaget, 2016. www.universitetsforlaget. no, http://www.universitetsforlaget.no/nettbutikk/skandinaviske-fortellinger-om-skyld-og-privilegier-i-en-globaliseringstid-uf.html.

Salice, Alessandro og Alba Montes Sánchez. "Pride, Shame, and Group Identification". Frontiers in Psychology 7 (2016): 557. Frontiers, doi:10.3389/fpsyg.2016.00557.

Salmela, Mikko og Gavin Brent Sullivan. "Commentary: Pride, Shame, and Group Identification". Frontiers in Psychology 7 (2016): 1946. Frontiers, doi:10.3389/ fpsyg.2016.01946.

Salmela, Mikko og Christian von Scheve. "Emotional Roots of Right-Wing Political Populism". Social Science Information 56, nr. 4 (2017): 567-595. SAGE Journals, doi:10.1177/0539018417734419.

Sartre, Jean-Paul. Being and Nothingness: An Essay on Phenomenological Ontology (2 udg.). Oversat af Hazel Barnes. London: Routledge, 2003.

Scheff, Thomas. Bloody Revenge: Emotions, Nationalism and War. Lincoln: iUniverse, 1994.

Scheler, Max. "Über Scham und Schamgefühl". Schriften aus dem Nachlass, Bd. 1: Zur Ethik und Erkenntnislehre. Bern: A. Francke AG Verlag, 1957. 65-154.

Smith, Richard H., et al.. "The role of public exposure in moral and nonmoral shame and guilt". Journal of Personality and Social Psychology 83, nr. 1 (2002): 138-59. APA PsycNET, doi:10.1037/0022-3514.83.1.138.

Tajfel, Henri. "Experiments in intergroup discrimination". Scientific American 223 (1970): 96-102.

Tajfel, Henri. "Social Categorization and Intergroup Behaviour". European Journal of Social Psychology 1, nr. 2 (1971): 149-78. Wiley Online Library, doi:10.1002/ejsp.2420010202.

Tangney, June Price og Ronda L. Dearing. Shame and Guilt. New York: Guilford Press, 2004. Tangney, June Price og Jeff Stuewig. "A Moral-Emotional Perspective on Evil Persons and Evil Deeds". The Social Psychology of Good and Evil. Red. Arthur G. Miller. New York: Guilford Press, 2004. 327-55.

Taylor, Gabriele. Pride, Shame, and Guilt: Emotions of Self-Assessment. Oxford: Clarendon Press, 1985.

Thomason, Krista K. "Shame, Violence, and Morality". Philosophy and Phenomenological 
Research 91, nr. 1 (2014): 1-24. Wiley Online Library, doi:10.1111/phpr.12110.

Turner, John C. "A Self-Categorization Theory". Rediscovering the Social Group, a Self-Categorization Theory. Red. John C. Turner. Oxford: Basil Blackwell, 1987. 42-67.

Turner, Jonathan H. "Self, Emotions, and Extreme Violence: Extending Symbolic Interactionist Theorizing". Symbolic Interaction 30, nr. 4 (2007): 501-30. Wiley Online Library, doi:10.1525/si.2007.30.4.501.

Whyte, Tim. "Generalsekretær i Mellemfolkeligt Samvirke: Sig fra over for det skammelige flygtningestop". Politiken 10. oktober 2017: Kroniken.

Williams, Bernard. Moral Luck: Philosophical Papers 1973-1980. Cambridge: Cambridge University Press, 1981.

Williams, Bernard. Shame and Necessity (2. udg.). Berkeley: University of California Press, 2008.

Wollheim, Richard. On the Emotions. New Haven: Yale University Press, 1999.

Zahavi, Dan. Self and Other, Exploring Subjectivity, Empathy, and Shame. Oxford: Oxford University Press, 2014.

Zahavi, Dan. Subjectivity and Selfhood, Investigating the First-Person Perspective. Cambridge MA: MIT Press, 2005.

Žižek, Slavoj. "Slavoj Žižek on White men's guilt \& politically correctness". The Žižek Times. Web 23. oktober 2017. http://www.zizektimes.com/2017/o9/slavoj-zizekon-white-mens-guilt.html. 